\title{
Growth and Stability of Litchi Production in Muzaffarpur District of Bihar, India
}

\author{
Janmejay Kumar* and Nikky Kumari \\ Dr. Rajendra Parsad Central Agricultural University, Pusa, Bihar \\ ATMA, Muzaffarpur, Bihar, India \\ *Corresponding author
}

\section{A B S T R A C T}

\section{Keywords}

Litchi, Growth, Area. Stability productivity, Muzaffarpur etc.

Article Info

\section{Accepted:}

05 April 2020

Available Online:

10 May 2020
This study in aimed at growth and stability of litchi production in Muzaffarpur district of Bihar with specific objectives of determining trend in area, production and productivity of litchi. India is the second largest producer of litchi in the world after China. Presently in India, litchi is cultivated in an area about 74.40 thousand hectares with total production of 483.60 thousand metric tons and productivity of 6.50 metric tons / hectare. Bihar produces nearly cultivated in an area about 31.1 thousand hectares with a total production of 227 thousand metric tons and productivity of 7.3 metric tons / hectare. It is mainly cultivated in the old district of Muzaffarpur, Champarn and Darbhanga. The study reveals that the growth rates in area, production and productivity is positive and found $2.76,3.82$ and 0.98, per cent respectively in India while in Bihar it is recorded 1.19, 3.02 and 1.75 per cent and negative rate $-0.19,-2.07$ and -2.03 per cent respectively in Muzaffarpur.

\section{Introduction}

Litchi (Litchi chinensis) is the important subtropical evergreen fruit crop, belonging to family sapindaceae and originated from china during 300 years ago. Litchi reached India through Myanmar by the end of the $17^{\text {th }}$ Century and then spread over in many tropical and subtropical area of the world. Its homeland, china still remains the biggest producer of litchi. India is the second largest litchi producing country in the world. Beside
India, it is cultivated extensively in temperature regions or Australia, South Africa, Thailand, Mauritius and Hongkong etc.

Litchi is famous for its excellent quality pleasant flavor and attractive red color. Litchi fruit contains about 60 percent Juice, 8 per cent of rag, 19 percent seed and 13 percent rind which depends upon the varieties and the climate under which it is grown. The principle chemical constituents are carbohydrates, 
organic acids, vitamins, pigments, protein and fat. Litchi fruit is considerably rich in sugar and the sugar content in fruit of Indian varieties varies from 6.74 to 18.0 per cent with the average of 11.85 per cent. Litchi is also an excellent source of vitamin ' $\mathrm{C}$ ' (ascorbic acid) ranging from 40.20 to 90 $\mathrm{mg} / 100 \mathrm{~g}$. It also contains protein (0.8-0.9\% fat $(0.3 \%)$ pectin $(0.42 \%)$ and minerals specially calcium phosphorus and iron (0.7 $\%$ ). Thus Litchi fruits add to the country's total production of bulky food over and its nutritive values, which is of ultimate utility at the present Juncture under nutrition.

Litchi is popular and delicious fruit of India. It cultivation is confined to Northern and some North-Eastern state of India. There has been substantial increase in area and production of litchi in India during last 50 years. Area has increased from 9,400 hectares (1949-50) to over 86,000 ha (2016-17). The contribution of litchi to total area under fruit has increased from 0.75 to nearly $2 \%$.Litchi has limited distribution in India particularly in the Indo-Gang tic plans form Bengal to Punjab. It is grown in the Bihar, Tripura, West Bengal, Uttrakhand, Uttar Pradesh, Punjab and Haryana of the total Production of litchi in India. 45 percent contributed by Bihar followed by W.B, Jharkhand, Assam and Chhatisgarh. Productivity is highest in Punjab which almost double to the National average. Litchi occupies an important place in the horticultural landscape of Bihar owing to its geographic confinement and the magnitude of its share to the overall production in the country.

Litchi is produced in 27 district of Bihar with 32,600 ha area 2, 15,100 matric tons of production and 7.0 metric tons /hectare productivity. (Indian Horticulture Data base 2015). In Bihar Litchi is mainly grown on large scale in the districts of North Bihar, Muzaffarpur, Samastipur, Vaishali, East
Champaran, West Champaran, Sitamarhi and Darbhanga. The Muzaffarpur district contributes highest area and production of litchi in state. Muzaffarpur is the largest litchi producing district with a production of 56.066 matric tones followed by Vaishali at 26,498 matric tones and Sitamarhi at 15,518 matric tones West Champaran and East Champaran and Katihar having of more than 10,000 matric tones.

\section{Materials and Methods}

Growth in area, production, productivity of litchi in Bihar and Muzaffarpur India

The data obtained on area, production, productivity of litchi for the period 2001-02 to 2015-16 in India, Bihar and Muzaffarpur were used for the estimation of compound growth rates. The data were computerized to get the compound growth rates in area, production, productivity.

\section{Compound growth rate}

The compound growth rates were estimated by fitting exponential foundation for the data. The equation fitted was of the following form

$\mathrm{Y}=a b^{\mathrm{t}}$

Where,

$\mathrm{Y}=\quad$ Area $\quad(000 \mathrm{ha}) /$ production

(000MT)/productivity (MT/ha)

$\mathrm{a}=$ constant

$b=$ Regression coefficient

$\mathrm{t}=$ time period in years.

Finally, the annual rate of compound growth in area, production and productivity of litchi were work out by using the formula

$r=($ Antilog $b-1) \times 100$ 
The significance of the estimated compound growth rates was tested with the help of student's ("T") test.

To know the variation in area, production, years, the co- efficient of variance (CV) was worked out by employing the following formula:

$\mathrm{CV}+$ standard division / mean X 100.

\section{Results and Discussion}

Trends in area, production and productivity of litchi in India

In this section an attempt has been made to analyze the compound growth rate (CGR) and per cent change in area production and productivity of the litchi in India and the data pertaining to it was accessed from the secondary source for a period of fifteen years (2001-02 to 2015-16). The area, production and productivity of litchi in India from 200102 to 2015-16 has been presented in the table: 1 The area under litchi cultivation in 2001-02 is seen as 58.10 thousand hectares in 2002-03 they are decreased to 54.10 thousand hectares i.e. -6.86 per cent over the previous year and it further decreased to 53.70 .

Hectares ( -0.73 per cent) in the subsequent year where as in 2004-05 they are increased to 60.00 thousands hectare thousands hectare (11.73 per cent) and again it further increased to 63.20 thousand hectares (5.33 per cent) in the year 2005-06, 65.00 thousands hectare (0.04 per cent) in the year 2006-07 and 69.00 thousand hectares (6.15 per cent) in 2007-08. Further in 2008-09 the area extended to 72.00 thousand hectares i.e. 4.34 per cent over the previous year and again it increased to 74.40 thousand hectares (3.33 per cent) in 2009-10. 78.00 thousand hectare ( 4.83 per cent) in the year 2010-11, 81.75 thousand hectare (4.81 per cent) in the year 2011-12, 83.00 thousand hectare (1.53 per cent) in the year 2012-13. Further in 2013-14, the area extended to 84.70 thousand hectare i.e. 2.05 per cent over the previous year 2014-15 the area increased 84.95 thousand hectare, finally in 2015-16 the area increased 85.00 thousand hectares i.e. 0.59 per cent over previous year increased in area of litchi cultivation from 2001-02 to 2015-16 was mainly due to remunerative price of litchi.

The production of litchi fruit in India in 200102 is seen as 355.90 thousand MT in 2002-03 it increased to 476.40 thousand MT (33.85 per cent) and it further increased marginally to 478.50 thousand MT (0.44 per cent) in subsequent year due to adoption of plant protection measures. Where as in 2004-05, the production decreased to 368.60 thousand MT (-22.96 per cent) and inter covered to 392.10 thousand MT (6.37 per cent) in the subsequent year in 2006-07. The production raised further to 403.00 thousand MT (2.77 per cent) in 2006-07 and it was 418.00 thousand MT (3.72 per cent) in the year 200708. In 2008-09 the production increased to 423.00 thousand MT (1.20 per cent) over the previous year in 2009-10 the production increased to 483.30 thousand (14.26 per cent) over the previous year. In 2010-11 it increased to 497.00 thousand MT (2.83 per cent) over the previous year and it increased to 538.13 thousand MT (8.28 per cent) over the previous year in 2011-12. The production level of litchi in India again increased in 2012-13 and 2013-14 to 580.00 thousand MT and 585.30 thousand MT respectively. In 2014-15 production level decreased to 528.26 thousand MT i.e. -9.75 per cent. Finally in 2015-16 production level increased comparatively previous year to 610.30 thousand MT i.e. 5.53 per cent over previous year.

The productivity of litchi fruit in India in 2001-02 is seen 6.1 MT/ha which increased to 
8.8 MT/ha 44.26 per cent in 2002-03 and 8.9 $\mathrm{MT} / \mathrm{ha}$ (1.13 per cent) in the year 2003-04, where in 2004-05.

The productivity decreased to $6.1 \mathrm{MT} / \mathrm{ha}$ (31.46 per cent) and then recovered to 6.2 MT/ha (1.63 per cent) in the year 2005-06. The productivity remained stable at 6.2 MT/ha in 2006-07 and 6.1 MT/ha in 2007-08 whereas 2008-09, the productivity decreased to $5.9 \mathrm{MT} / \mathrm{ha}(-3.28$ per cent) and then recovered to $6.5 \mathrm{MT} / \mathrm{ha}$ (10.17 per cent) in the year 2009-10. The productivity decreased to 6.4 MT/ha in 2010-11 (-1.54 per cent) and it marginally increased to $6.5 \mathrm{MT} / \mathrm{ha}$ in 2011 12. Where as in 2012-13, the productivity increased to $6.9 \mathrm{MT} / \mathrm{ha}$ (6.15) over the previous year and it remained stable to 6.9 MT/ha in the subsequent year in 2014-15, the productivity decreased to $6.3 \mathrm{MT} / \mathrm{ha}(-8.70$ per cent). Finally in 2015-16 the productivity same increased to $6.6 \mathrm{MT} / \mathrm{ha}$ (4.55 per cent) over the previous year.

The compound growth rates for area production and productivity were 2.76 per cent, 3.83 per cent and productivity 0.98 per cent respectively.

Trends in area, production and productivity of litchi in Bihar

In this section an attempt has been made to analyze the compound growth rate (CGR) and per cent change in area, production and productivity at the litchi in Bihar for the period of fifteen tears (2001-02 to 2015-16).

The area, production and productivity of litchi in Bihar from 2001-02 to 2015-16 has been in table- 2. The area under litchi in 2001-02 is seen as 27.70 thousand hectares where as in 2002-03 the area increased to 29.10 thousand hectare $(-2.74$ per cent) in the subsequent year. Similarly in 2004-05, the area increased to 28.40 thousand hectares ( 0.35 per cent) and it remained constant at 28.40 thousand hectares in subsequent year. Further in 200607 , the area increased to 28.80 thousand hectares (3.47 per cent) in the subsequent year. Similarly, in 2008-09 the area increased to 30.5 thousand hectares ( 2.35 per cent) and it increased to 30.6 thousand hectares in the subsequent year. Further, in 2010-11 the area increased to 31.1 thousand hectares (1.63 per cent).

The production of litchi in Bihar 2001-02 was 221.7 thousand MT in 2002-03 it increased to 336.9 thousand MT i.e. 51.96 per cent increases over the previous year which is quit a substantial growth due to increased productivity level and it further increased to 339.0 thousand MT (0.62 per cent) in subsequent year. In 2004-05, the production decreased to 204.9 thousand MT i.e. -39.55 per cent a decline over the previous year and further again it decreased to 200.1 thousand MT (-2.34 per cent) in the subsequent year. In 2006-07 the production increased further to 211.9 thousand MT (5.89 per cent) over the previous year and 223.2 thousand MT (5.33 per cent) in the subsequent year. In 2008-09, the production declined marginally to 2016.9 thousand MT (-2.82 per cent) and 215.1 thousand MT (-0.82 per cent) in the subsequent year. In 2010-11, the production increased to 227.0 thousand MT i.e. 5.53 per cent over the previous year. In 2011-12 the production increased 256.2 thousand MT i.e. 11.39 per cent and 2012-13 the production increased in 310.2 thousand MT and percentage decline in 3.68 in 2013-14 the production increased 321.6 thousand MT i.e. (3.16 per cent) i.e. in the year 2014-15 the production increased to 332.1 per cent MT i.e. 3.16 per cent respectively. Finally in 2015-16 the production increased to $336.4 \mathrm{mt}$ i.e. 1.28 per cent over the previous year.

The productivity of litchi fruit in Bihar in 2001-02 shows that $8.0 \mathrm{mt} / \mathrm{ha}$ and in 2002-03 
it increased to $11.6 \mathrm{mt} / \mathrm{ha}$ (45 per cent) and further it increased to $12.0 \mathrm{mt} / \mathrm{ha}$ (3.44 per cent) in the subsequent year. In 2004-05, the productivity decreased to $7.2 \mathrm{mt} / \mathrm{ha}$ ( -40 per cent) and letter slightly improved to $7.0 \mathrm{mt} / \mathrm{ha}$ $(-2.77$ per cent) in the year in the subsequent year. In 2006-07, the productivity increased to $7.4 \mathrm{mt} /$ ha i.e. 5.71 per cent over the previous year and it further increased to $7.5 \mathrm{mt} /$ ha in the subsequent year. In 2008-09, the productivity decreased by 5.33 per cent and again it decreased by 1.40 per cent in the subsequent year. In 2010-11, the productivity increased to $7.3 \mathrm{mt} / \mathrm{ha}$ (4.28 per cent) in 2011-12, the productivity 8.0 increased by 9.56 per cent and again 2012-13 the productivity increased $9.6 \mathrm{mt} / \mathrm{ha}$ i.e. (20.00 per cent) then 2013-14 the productivity increased $10.2 \mathrm{mt} /$ ha and 3.03 per cent. Finally in $2015-16$, the productivity increased to $10.3 \mathrm{mt} / \mathrm{ha}$ ( 0.98 per cent).

The compound growth rates for area, production and productivity were 1.19, per cent 3.02 per cent and 1.15 per cent respectively. Among the all these variables has shown significant growth rate is similar to the trend at all India level.

In this section an attempt has been made of analyze the compound growth rate (CGR) and per cent change in area, production and productivity of litchi in Muzaffarpur district of Bihar for fifteen years (2001-02 to 201516).

The area, production and productivity of litchi in Muzaffarpur district from 2001-02 to 201516 has been presented in the table- 3 .

The area under litchi in 2001-02 is seen as 7,517 ha where as in 2002-03 the area increased to 7,667 ha where as it remained constant at 7,667 ha in the subsequent year. In 2004-05, the area decreased by 6.44 per cent over the previous year and again it further declined by 0.47 per cent in $2005-06$ where as in 2006-07, the area increased to 7,157 ha i.e. 0.25 per cent increased over the previous year and further to 7,206 ha in 2007-08 the area increased by 0.31 per cent in 2008-09 over the previous year and by 0.33 per cent in the subsequent year. In 2010-11the area under litchi increased to 7.28 /ha (0.38 per cent) increased over the previous year and further to 7289 ha in 2011-12. The area increased by 0.15 per cent in 2012-13 over the previous year and it remains unchanged in the subsequent year. In 2014-15 the area under litchi declined by 0.03 per cent. Finally in 2015-16 the area same increased 7303 ha i.e. 0.06 per cent.

The production of litchi fruit in Muzaffarpur district of Bihar in 2001-02 was 74000 MT in 2002-03 it decreased to $53.000 \mathrm{mt}$ (-28.30 per cent and it increased to $75000 \mathrm{mt}(41.50$ per cent) in subsequent year. In 2004-05, the production increased to 85,548 MTi.e. 14.06 per cent rise over the previous year and it slightly decreased to $57096 \mathrm{mt}$ (-33.25 per cent) in the subsequent year due to under able climatic conditions. In 2006-07, the production slightly declined to $52687 \mathrm{mt}$ and it marginal increased to 55826 MT in 2007-08. In 2008-09 the production decreased to 54322 MT and further to 51496 MT in the subsequent year. Whereas during the year 2010-11 the production increased by 4.62 per cent over the previous year. The production slightly increased to $53879 \mathrm{mt}$ and it marginal increased to 53886mt in 2011-12. In 2012-13 the production increased to $58980 \mathrm{mt}$ and it remains same in the subsequent year. In 201415 the production decreased by 5.48 per cent. Where during the year 2015-16 the production decreased by 1.08 per cent over the previous year.

The productivity of litchi in Muzaffarpur district of Bihar in 2001-02 was 10-0mt/ha. In 2002-03 it was decreased to 6.0 MT/ha and it marginally increased to $9.7 \mathrm{MT} /$ ha (61.66 per 
cent) in the subsequent year. In 2004-05, the productivity further increased to $11.9 \mathrm{mt} / \mathrm{ha}$ (22.68) and it decreased to $7.9 \mathrm{mt} / \mathrm{ha}(-33.6$ per cent in the 2005-06, 7.3 MT/ha in 200607 and it increased to $7.7 \mathrm{mt} / \mathrm{ha}$ (5.47 per cent) in the year 2007-08 in 2008-09, the productivity declined by 2.59 per cent over the previous year and again it further declined by 5.33 per cent in the subsequent year. In 2010-11 and it increased to $7.4 \mathrm{MT} / \mathrm{ha}$ (4.2 per cent). In 2011-12 the productivity remains unchanged over the previous year and it further increased by 9.5 per cent in the subsequent year. In 2014-15 the productivity declined to $7.6 \mathrm{MT} / \mathrm{ha}$ i.e. (-6.2 per cent). Finally in 2015-16, the productivity decreased to $7.5 \mathrm{mt} /$ ha i.e. (-1.3 per cent) over the previous year. The compound growth rates for area, production and productivity were -0.19 , -2.07 and -2.03 per cent respectively.

In conclusion, growth and stability the area under litchi has increased significantly both in Bihar and India, but production has declined significantly in Muzaffarpur, while in India it has increased but not significantly. The productivity has declined significantly in Muzaffarpur and India both which resulted in decreased production even there was significant increase in area.

Table.1 Percentage change and growth rates in area, production and productivity of litchi in India (2001-02 to 2015-16)

\begin{tabular}{|c|c|c|c|c|c|c|c|}
\hline $\begin{array}{c}\text { S. } \\
\text { No. }\end{array}$ & Year & $\begin{array}{c}\text { Area in } \\
\mathbf{1 0 0 0} \text { ha }\end{array}$ & $\begin{array}{c}\text { Percentage } \\
\text { over } \\
\text { previous }\end{array}$ & $\begin{array}{c}\text { Production } \\
\text { in 1000 } \\
\text { MT }\end{array}$ & $\begin{array}{c}\text { Percentage } \\
\text { over } \\
\text { previous } \\
\text { year }\end{array}$ & $\begin{array}{c}\text { Productivity } \\
\text { (in MT/ha) }\end{array}$ & $\begin{array}{c}\text { Percentage } \\
\text { over } \\
\text { previous } \\
\text { year }\end{array}$ \\
\hline $\mathbf{1 .}$ & $2001-02$ & 58.10 & - & 355.90 & - & 6.10 & - \\
\hline $\mathbf{2 .}$ & $2002-03$ & 54.10 & -6.88 & 476.40 & 33.85 & 8.8 & 44.26 \\
\hline $\mathbf{3 .}$ & $2003-04$ & 53.70 & -0.73 & 478.50 & 0.44 & 8.9 & 1.13 \\
\hline $\mathbf{4 .}$ & $2004-05$ & 60.00 & 11.73 & 368.60 & -22.96 & 6.1 & -31.46 \\
\hline $\mathbf{5 .}$ & $2005-06$ & 63.20 & 5.33 & 392.10 & 6.37 & 6.2 & 1.63 \\
\hline $\mathbf{6 .}$ & $2006-07$ & 65.00 & 0.04 & 403.00 & 2.77 & 6.2 & 0 \\
\hline $\mathbf{7 .}$ & $2007-08$ & 69.00 & 6.15 & 418.00 & 3.72 & 6.1 & -1.61 \\
\hline $\mathbf{8 .}$ & $2008-09$ & 72.00 & 4.34 & 423.00 & 1.19 & 5.9 & -3.28 \\
\hline $\mathbf{9 .}$ & $2009-10$ & 74.40 & 3.33 & 483.30 & 14.25 & 6.5 & 10.17 \\
\hline $\mathbf{1 0 .}$ & $2010-11$ & 78.00 & 4.83 & 497.00 & 2.83 & 6.4 & -1.54 \\
\hline $\mathbf{1 1 .}$ & $2011-12$ & 81.75 & 4.81 & 538.13 & 8.28 & 6.5 & 1.56 \\
\hline $\mathbf{1 2}$ & $2012-13$ & 83.00 & 1.53 & 580.00 & 7.78 & 6.9 & 6.15 \\
\hline $\mathbf{1 3 .}$ & $2013-14$ & 84.70 & 2.05 & 585.30 & 0.91 & 6.9 & 0.00 \\
\hline $\mathbf{1 4}$ & $2014-15$ & 84.95 & 0.30 & 528.26 & -9.75 & 6.3 & -8.70 \\
\hline $\mathbf{1 5}$ & $2015-16$ & 85.00 & 0.59 & 610.30 & 15.53 & 66 & 4.55 \\
\hline & Percent change in over & & 46.30 & & 71.48 & - & 8.20 \\
\hline & $2001-02$ to 2015-16 & & & & & & \\
\hline & CGR & 2.76 & & 3.83 & & 0.98 & \\
\hline
\end{tabular}

1\% - 2.977 Significant,5\% - 2.145 Significant 
Table.2 Percentage change and growth rate in area, production and productivity of litchi in Bihar

\begin{tabular}{|c|c|c|c|c|c|c|c|}
\hline $\begin{array}{c}\text { S. } \\
\text { No. }\end{array}$ & Year & $\begin{array}{c}\text { Area } \\
(\mathbf{1 0 0 0 h a )}\end{array}$ & $\begin{array}{c}\text { Per cent change } \\
\text { over previous } \\
\text { year }\end{array}$ & $\begin{array}{c}\text { Production } \\
\text { (1000mt) }\end{array}$ & $\begin{array}{c}\text { Per cent change } \\
\text { over previous } \\
\text { year }\end{array}$ & $\begin{array}{c}\text { Yield } \\
\text { mt/ha }\end{array}$ & $\begin{array}{c}\text { Per cent change } \\
\text { over previous } \\
\text { year }\end{array}$ \\
\hline $\mathbf{1 .}$ & $2001-02$ & 27.7 & - & 221.7 & - & 8.0 & - \\
\hline $\mathbf{2 .}$ & $2002-03$ & 29.1 & 5.05 & 336.9 & 51.96 & 11.6 & 4.5 \\
\hline $\mathbf{3 .}$ & $2003-04$ & 28.3 & -2.74 & 339.0 & 0.62 & 12.0 & 3.44 \\
\hline $\mathbf{4 .}$ & $2004-05$ & 28.4 & 0.35 & 204.9 & -39.55 & 7.2 & -40 \\
\hline $\mathbf{5 .}$ & $2005-06$ & 28.4 & 0.00 & 200.1 & -2.34 & 7.0 & -2.77 \\
\hline $\mathbf{6 .}$ & $2006-07$ & 28.8 & 1.40 & 211.9 & 5.89 & 7.4 & 5.71 \\
\hline $\mathbf{7 .}$ & $2007-08$ & 29.8 & 3.47 & 223.2 & 5.33 & 7.5 & 1.35 \\
\hline $\mathbf{8 .}$ & $2008-09$ & 30.5 & 2.34 & 216.9 & -2.82 & 7.1 & -5.33 \\
\hline $\mathbf{9 .}$ & $2009-10$ & 30.6 & 0.32 & 215.1 & -0.82 & 7.0 & -1.40 \\
\hline $\mathbf{1 0}$ & $2010-11$ & 31.1 & 1.63 & 227.0 & 5.53 & 7.3 & 4.28 \\
\hline $\mathbf{1 1}$ & $2011-12$ & 31.8 & 0.94 & 256.2 & 11.39 & 8.0 & 9.58 \\
\hline $\mathbf{1 2}$ & $2012-13$ & 32.1 & 0.93 & 310.2 & 3.68 & 9.6 & 20.00 \\
\hline $\mathbf{1 3}$ & $2013-14$ & 32.4 & 0.00 & 321.6 & 3.36 & 9.9 & 3.12 \\
\hline $\mathbf{1 4}$ & $2014-15$ & 32.4 & 0.00 & 332.1 & 3.16 & 10.2 & 3.03 \\
\hline $\mathbf{1 5}$ & $2015-16$ & 32.7 & 0.91 & 336.4 & 1.28 & 10.3 & 0.98 \\
\hline & Per cent change in & & 18.05 & & & & \\
\hline
\end{tabular}

Note: - ${ }^{* *}$ significantly at 1 per cent level of probability. ${ }^{*}$ Significant at 5 Per cent level of probability2011-12 the area some increase in 31.8 thousand hectare (0.94 per cent) and 2012-13 percentage decrease in 0.93 the year 2013-14 and 2014-15 same the subsequent area and percentage finally in 2015-16. The area was increased to 32.7 thousand hectare i.e. 0.91 per cent over the previous year. The increased trend is the better return being received by the litchi growers.

Table.3 Trends in area, production and productivity of litchi in Muzaffarpur district of Bihar

\begin{tabular}{|c|c|c|c|c|c|c|c|}
\hline S. No. & Year & $\begin{array}{c}\text { Area } \\
\text { (ha) }\end{array}$ & $\begin{array}{c}\text { Per cent } \\
\text { over } \\
\text { previous } \\
\text { year }\end{array}$ & $\begin{array}{c}\text { Production } \\
\text { (MT) }\end{array}$ & $\begin{array}{c}\text { Per cent } \\
\text { change over } \\
\text { previous } \\
\text { year }\end{array}$ & $\begin{array}{c}\text { Productivity } \\
\text { MT/ha }\end{array}$ & $\begin{array}{c}\text { Per cent } \\
\text { change over } \\
\text { previous } \\
\text { year }\end{array}$ \\
\hline $\mathbf{1 .}$ & $2001-02$ & 7517 & - & 74000 & - & 10.0 & - \\
\hline $\mathbf{2 .}$ & $2002-03$ & 7667 & 1.99 & 53000 & -28.30 & 6.0 & -40.00 \\
\hline $\mathbf{3 .}$ & $2003-04$ & 7667 & 0.00 & 75000 & 41.50 & 9.7 & 61.66 \\
\hline $\mathbf{4 .}$ & $2004-05$ & 7173 & -6.44 & 85548 & 14.06 & 11.9 & 22.68 \\
\hline $\mathbf{5 .}$ & $2005-06$ & 7139 & -0.47 & 57096 & -33.25 & 7.9 & -33.60 \\
\hline $\mathbf{6 .}$ & $2006-07$ & 7157 & 0.25 & 52687 & -7.72 & 7.3 & -7.59 \\
\hline $\mathbf{7 .}$ & $2007-08$ & 7206 & 0.68 & 55826 & 5.95 & 7.7 & 5.47 \\
\hline $\mathbf{8 .}$ & $2008-09$ & 7229 & 0.31 & 54322 & -25.81 & 7.5 & -2.59 \\
\hline $\mathbf{9 .}$ & $2009-10$ & 7253 & 0.33 & 51496 & -5.20 & 7.1 & -5.33 \\
\hline $\mathbf{1 0 .}$ & $2010-11$ & 7281 & 0.38 & 53879 & 4.62 & 7.3 & 2.81 \\
\hline $\mathbf{1 1 .}$ & $2011-12$ & 7289 & 0.11 & 53886 & 0.01 & 7.3 & 0.0 \\
\hline $\mathbf{1 2 .}$ & $2012-13$ & 7300 & 0.15 & 58980 & 9.45 & 8.1 & 9.5 \\
\hline $\mathbf{1 3 .}$ & $2013-14$ & 7300 & 0.00 & 58980 & 0.00 & 8.1 & 0.00 \\
\hline $\mathbf{1 4 .}$ & $2014-15$ & 7298 & -0.03 & 55746 & -5.48 & 7.6 & -6.2 \\
\hline $\mathbf{1 5 .}$ & $2015-16$ & 7303 & 0.06 & 55146 & -1.08 & 7.5 & -1.3 \\
\hline & Per cent change in & & -2.84 & & -25.48 & & -25 \\
\hline
\end{tabular}

Note: - ${ }^{* *} 1 \%$ Level of significance at probability ${ }^{*} 5 \%$ Level of significance at probability 

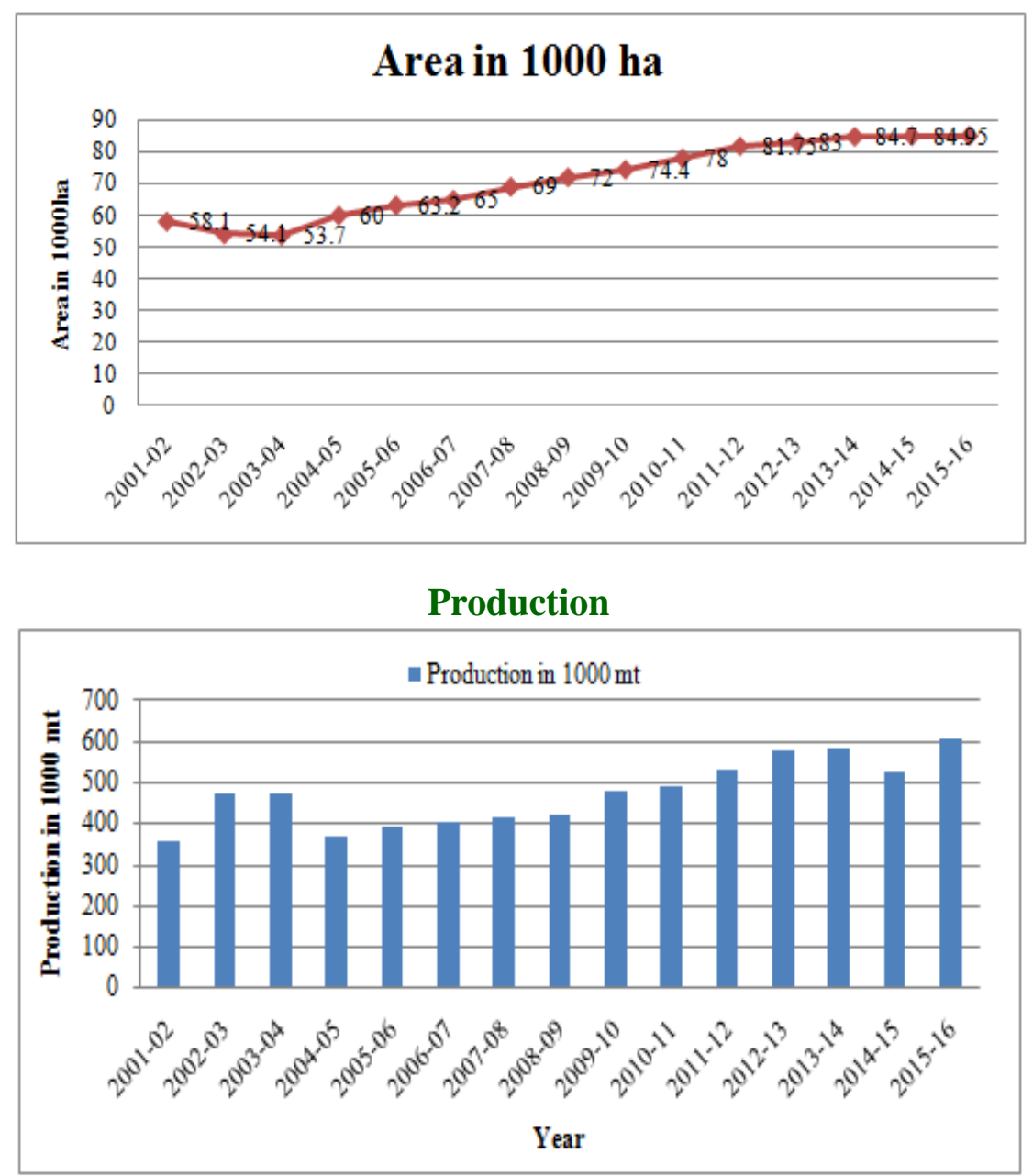

\section{Productivity}

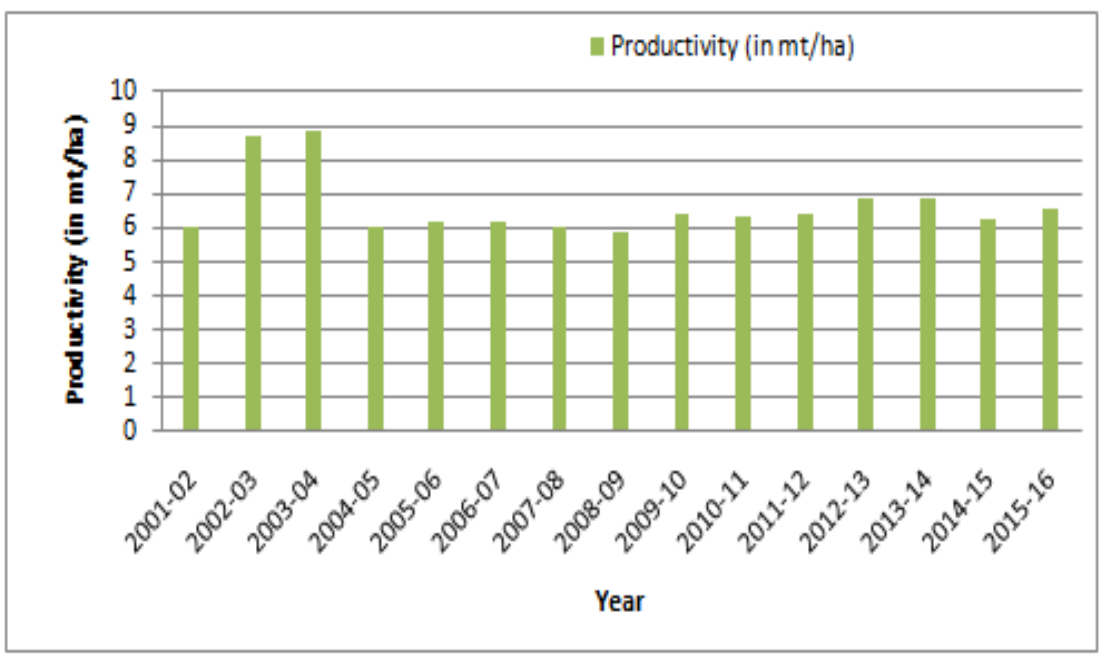


Area.
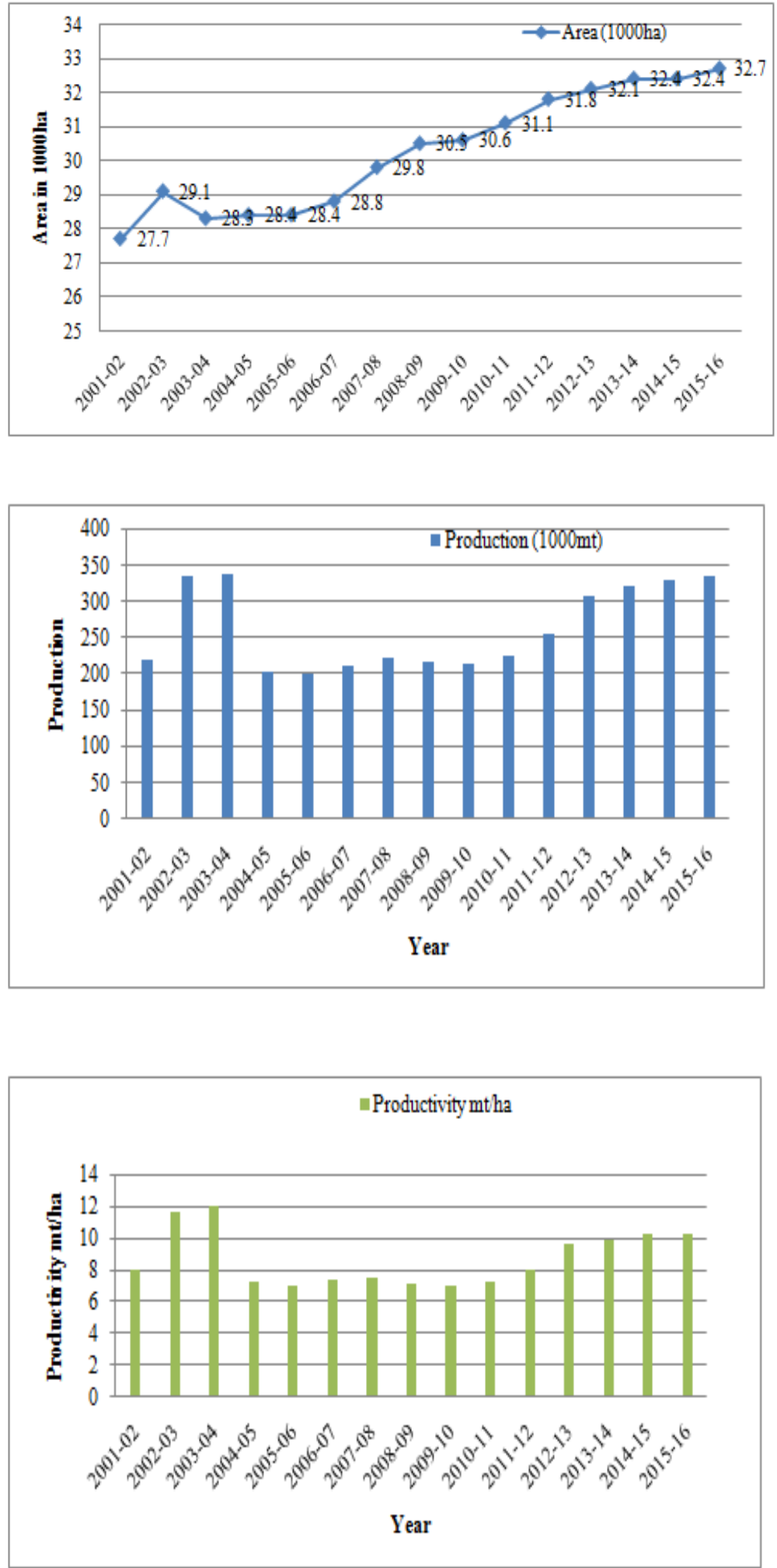
Area

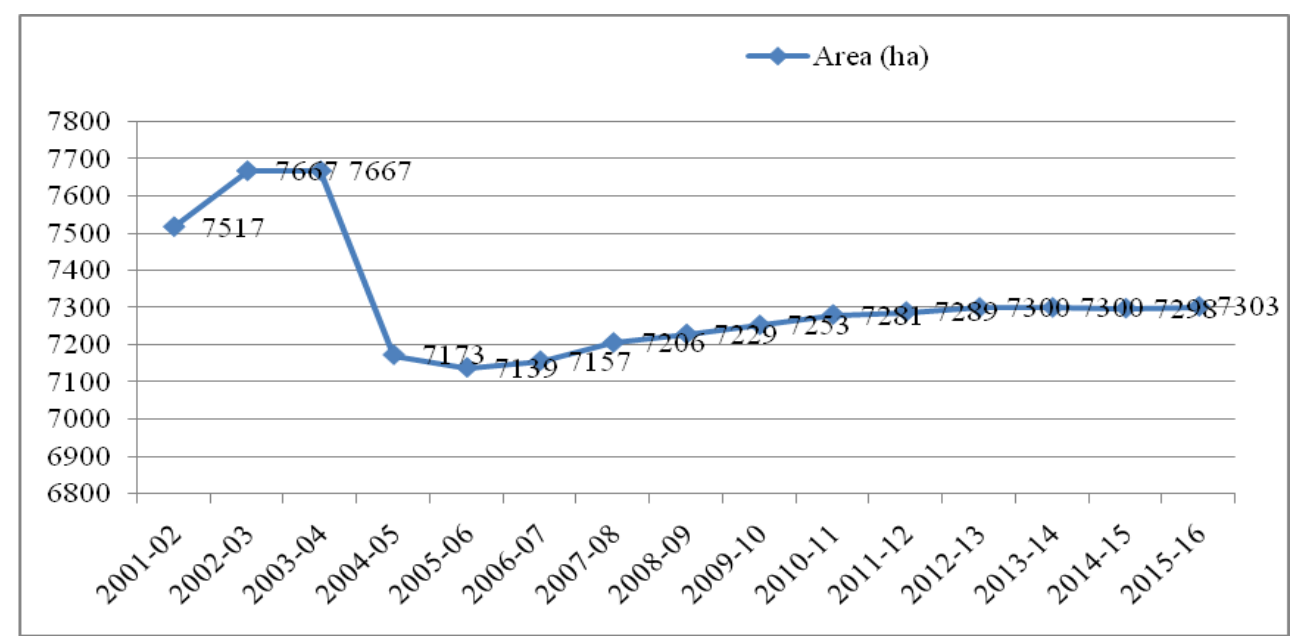

Production

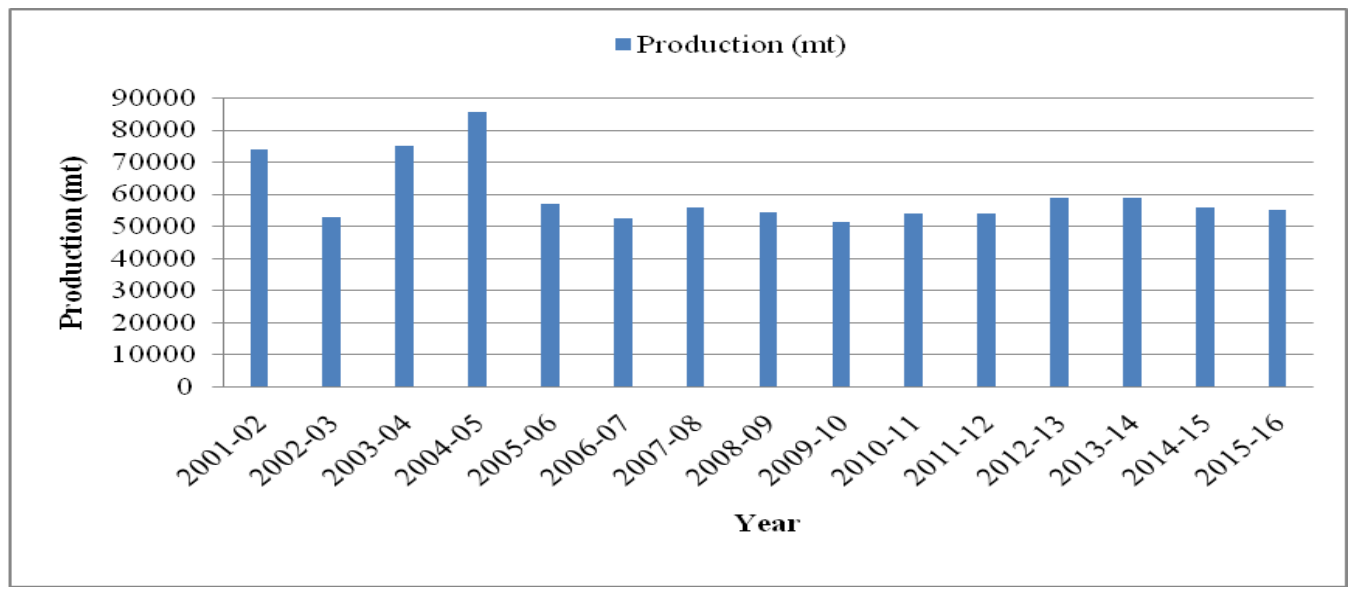

Productivity

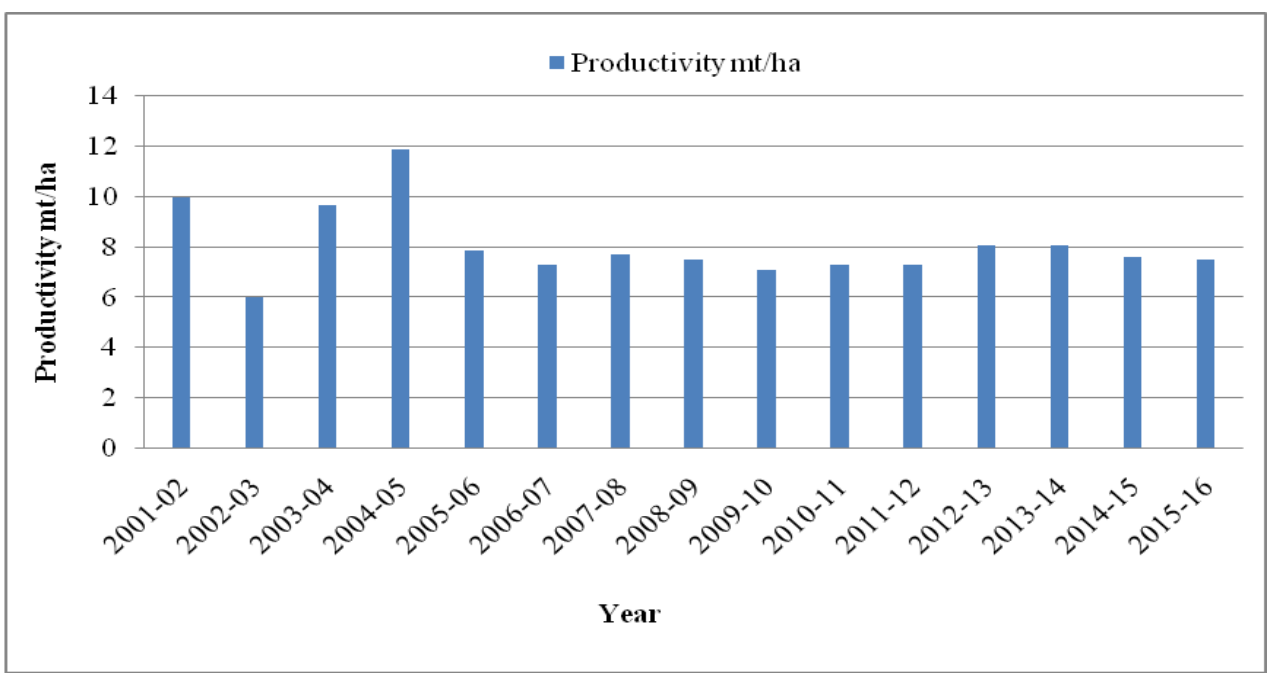


Hectares ( -0.73 per cent) in the subsequent year where as in 2004-05 they are increased to 60.00 thousands hectare thousands hectare (11.73 per cent) and again it further increased to 63.20 thousand hectares (5.33 per cent) in the year 2005-06, 65.00 thousands hectare (0.04 per cent) in the year 2006-07 and 69.00 thousand hectares (6.15 per cent) in 2007-08. Further in 2008-09 the area extended to 72.00 thousand hectares i.e. 4.34 per cent over the previous year and again it increased to 74.40 thousand hectares (3.33 per cent) in 2009-10. 78.00 thousand hectare (4.83 per cent) in the year $2010-11,81.75$ thousand hectare (4.81 per cent) in the year 2011-12, 83.00 thousand hectare (1.53 per cent) in the year 2012-13. Further in 2013-14, the area extended to 84.70 thousand hectare i.e. 2.05 per cent over the previous year 2014-15 the area increased 84.95 thousand hectare, finally in $2015-16$ the area increased 85.00 thousand hectares i.e. 0.59 per cent over previous year increased in area of litchi cultivation from 2001-02 to 2015-16 was mainly due to remunerative price of litchi.

The production of litchi fruit in India in 200102 is seen as 355.90 thousand MT in 2002-03 it increased to 476.40 thousand MT (33.85 per cent) and it further increased marginally to 478.50 thousand MT (0.44 per cent) in subsequent year due to adoption of plant protection measures. Where as in 2004-05, the production decreased to 368.60 thousand MT (-22.96 per cent) and inter covered to 392.10 thousand MT (6.37 per cent) in the subsequent year in 2006-07. The production raised further to 403.00 thousand MT (2.77 per cent) in 2006-07 and it was 418.00 thousand MT (3.72 per cent) in the year 2007 08. In 2008-09 the production increased to 423.00 thousand MT (1.20 per cent) over the previous year in 2009-10 the production increased to 483.30 thousand ( 14.26 per cent) over the previous year. In 2010-11 it increased to 497.00 thousand MT (2.83 per cent) over the previous year and it increased to 538.13 thousand MT (8.28 per cent) over the previous year in 2011-12. The production level of litchi in India again increased in 2012-13 and 2013-14 to 580.00 thousand MT and 585.30 thousand MT respectively. In 2014-15 production level decreased to 528.26 thousand MT i.e. -9.75 per cent. Finally in 2015-16 production level increased comparatively previous year to 610.30 thousand MT i.e. 5.53 per cent over previous year.

The productivity of litchi fruit in India in 2001-02 is seen 6.1 MT/ha which increased to 8.8 MT/ha 44.26 per cent in 2002-03 and 8.9 MT/ha (1.13 per cent) in the year 2003-04, where in 2004-05.

The productivity decreased to $6.1 \mathrm{MT} / \mathrm{ha}$ (31.46 per cent) and then recovered to 6.2 MT/ha (1.63 per cent) in the year 2005-06. The productivity remained stable at 6.2 MT/ha in 2006-07 and 6.1 MT/ha in 2007-08 whereas 2008-09, the productivity decreased to $5.9 \mathrm{MT} / \mathrm{ha}(-3.28$ per cent) and then recovered to $6.5 \mathrm{MT} / \mathrm{ha}$ (10.17 per cent) in the year 2009-10. The productivity decreased to 6.4 MT/ha in 2010-11 (-1.54 per cent) and it marginally increased to $6.5 \mathrm{MT} / \mathrm{ha}$ in 201112. Where as in 2012-13, the productivity increased to $6.9 \mathrm{MT} / \mathrm{ha}$ (6.15) over the previous year and it remained stable to 6.9 MT/ha in the subsequent year in 2014-15, the productivity decreased to $6.3 \mathrm{MT} / \mathrm{ha}(-8.70$ per cent). Finally in 2015-16 the productivity same increased to $6.6 \mathrm{MT} / \mathrm{ha}$ (4.55 per cent) over the previous year.

The compound growth rates for area production and productivity were 2.76 per cent, 3.83 per cent and productivity 0.98 per cent respectively.

\section{References}

Choubey, Manesh(1997). A study on 
production and marketing of litchi (Litchi chinensis) in Bihar. M.Sc. (Agri.) (Unpublished) Thesis, Department of Agricultural Economics, Indian Agricultural Research Institute, New Delhi.

Kanwar, J.S. and G.S., Nijjar (1984). Comparative evaluation of fruit growth in relation to cracking of fruit in some litchi cultivars. The Punjab horticultural journal, XXIII (1-4):82

Kumar, Ram and Kotur S. P. (1992). Litchi survey in Muzafarpur area of North Bihar. National seminar on recent development in litchi production, May 30-31 at Pusa. Pp. 7-8.

Kumar, Suresh (1997). A study of dynamics of production and marketing of litchi in Muzaffarpur district of Bihar. M.Sc. (Agri.) (Unpublished) Thesis, Rajendra Agricultural University, Pusa.

Pandey, R.M. (1990). Horticultural crops New vista for growth. The Hindu Survey of India Agriculture. P.P. 177181.
Prasad Lallan Kumar (1993). Why maximum production of litchi in Muzaffarpur. Nav Bharat Times, (Hindi) July 7.

Ray, P.K. (2004) Litchi production technology and postharvest handling for export Rajendra Agricultural University, Pusa : 28

RumanaAkter, M. Serajul Islam and Golam Rabbani (2016). Financial analysis of litchi (Litchi chinensis) production in Dinajpur district of Bangladesh. The Agricultrist 14 (2) 32.

Singh, H. P. (2017). Dynamic of Research and Development of Litchi: Way forward. Former, DDG, ICAR. Gyanmatharn, vol. VI, National conference on perspective of challenges and option in Litchi Production and Utilization. 6-7 June 2017. ICARNational Research Center on Litchi, Muzaffarpur,Bihar.37.A Scientific Journal of Krishi Foundation.

\section{How to cite this article:}

Janmejay Kumar and Nikky Kumari. 2020. Growth and Stability of Litchi Production in Muzaffarpur District of Bihar, India. Int.J.Curr.Microbiol.App.Sci. 9(05): 708-719. doi: https://doi.org/10.20546/ijcmas.2020.905.079 